\title{
FACTORS INFLUENCING THE DESIGN OF MOBILE SERVICES
}

\author{
Michael Amberg, Jens Wehrmann and Ralf Zimmer \\ Chair for Business Information Technology, University of Erlangen-Nuremberg, Lange Gasse \\ 20, 90403 Nuremberg, Germany. Telephone: +49-911-5302-800; Fax: +49-911-5302-802, \\ Email: \{michael.amberg; jens.wehrmann; ralf.zimmer\}@wiso.uni-erlangen.de
}

Abstract: Due to emerging technologies and a high speed of innovation the planning and development process of mobile services is highly dynamic. Numerous failures of mobile services emphasise the need for a comprehensive analysis of all relevant influencing factors. A widely accepted understanding of the number and type of factors to be analysed during the development of mobile services does not exist.

This paper provides a theory based framework that helps to identify a balanced set of relevant influencing factors. For this purpose the contribution of different scientific approaches is examined. By combining these approaches a framework for the classification is derived within a two step process. First experiences confirmed its suitability for the systematic classification of factors influencing the design of mobile services.

Key words: Classification of Influencing Factors; Theory Based Classification Framework; Design of Mobile Services

\section{MOTIVATION}

Mobile services for end-users (e.g. messaging, navigation, yellow pages, chats) are more and more influencing our private life. The Gartner Group estimates the annual turnover for mobile services in 2005 to be more than 32 billion US $\$$ with a rapidly growing trend in the future ${ }^{1}$. In contrast to the development of regular end-user products the development of mobile 
services is characterised by a permanent and frequent appearance of new technologies. This makes the planning and development process of mobile services highly dynamic ${ }^{2}$.

Potential end-users often do not recognize the added value or are not willing to pay the price for a specific mobile service. Even extensive marketing campaigns do not lead to a satisfying dissemination and revenue of a broad spectrum of mobile services. As a consequence mobile services are often not developed any further, marketing campaigns are stopped or the services are displaced.

Böcker and Kotzbauer empirically verify the positive coherence between systematic planning of an innovation and its success ${ }^{3}$. Influencing factors that are not adequately considered may lead to an incomplete or incorrect specification of mobile services. As any misinterpretation affects all following phases of development, the analysis and planning process is particularly important for the design of a mobile service ${ }^{4,5}$.

To support these processes scientific approaches help to manage the existing complexity. Models that especially focus on mobile services and regard the identification of influencing factors are not established. According to this lack of suitable approaches this paper discusses different approaches for an identification of influencing factors in a two step process. Chapter 2 presents four basic dimensions for a classification of influencing factors. Chapter 3-6 discusses a sub-division for each of these dimensions. Chapter 7 summarises the results, chapter 8 gives an outlook.

\section{CLASSIFICATION OF INFLUENCING FACTORS}

For a systematic planning process there is a need for a comprehensive, complete and disjunctive classification of influencing factors of mobile services. Regarding the state of the art literature leads to several classifications that either provide an abstract overview or regard parts of the entirety of influencing factors more detailed. These detailed approaches do not identify concrete influencing factors in general, but provide classifications with a level of abstraction that is regarded as appropriate for identifying influencing factors for specific mobile services.

The combination of general and detailed approaches leads to a two step process for the classification of influencing factors of mobile services ${ }^{6}$. In a first step general dimensions can be identified. In a second step these dimensions can be subdivided to permit the identification of tangible influencing factors of mobile services.

In the first step mobile services can be divided into the four dimensions Structure, Process, Outcomes and Market ${ }^{6,7}$. This classification traces back 
to several approaches that identify the first three dimensions for a systematic service engineering ${ }^{8-11}$. Taking external dependencies of mobile services into account these dimensions can be extended by the fourth dimension Market ${ }^{7}$. Amberg et al. give a detailed overview of current state of the art approaches ${ }^{6}$.

The Structure dimension describes the required input factors for the service development ${ }^{12}$. The Process dimension represents all required processes during the product lifecycle ${ }^{11}$. The Outcome of a mobile service can be divided into procedural outcome and impact of the outcome ${ }^{13,14}$. The procedural outcome can be evaluated at the end of the service provision. The impact of the mobile service has a medium or long term character (continuous quality) ${ }^{15}$. Especially for mobile services the Outcomes focus on the result of the process from the end-user's perspective. This is significantly determined by the end-user's acceptance ${ }^{16}$. Thus, the dimension Outcomes is termed Acceptance in the following. The relevant actors of the mobile value chain are regarded in the Market dimension ${ }^{4}$.

As a result of the first step the dimensions Structure, Process, Acceptance and Market classify the influencing factors completely and disjunctive. In the second step these dimensions can be subdivided into feasible sub-dimensions ${ }^{6}$. Chapter 3-6 discusses different approaches for a subdivision in detail. The choice of suitable approaches is based on the originality of approaches, the suitability for mobile services and a feasible level of abstraction.

\section{STRUCTURE DIMENSION}

A mobile service can be defined as a combination of internal potentials and usage factors (resources) ${ }^{5,17}$. The Structure dimension focuses on the provision of mobile services i.e. the capability and willingness to combine internal potential factors to be able to provide a service ${ }^{12}$.

Regarding theories that subdivide this dimension leads to a variety of different approaches. Significant models are McKinsey's 7-S Model that focuses on change management and emphasises mutual dependencies of dimensions, Pfeiffer's Five Factors Model that is based on a procedural analysis of industrial processes in general and Porter's Value Chain Model that describes support activities for any kind of product or service. Most of the further approaches are derivates of Porter's Value Chain Model and do not offer additional perceptions for a subdivision of the Structure dimension.

McKinsey's 7-S Model identifies seven significant elements of an organization: Strategy, structure, systems, style/culture, staff, skills and shared values. Any change in one of the elements affects all others ${ }^{18}$. 
Pfeiffer provides a Five Factor Model that describes the structural and procedural dimensions of industrial systems. It identifies the dimensions input, personnel, organisation, technology and output ${ }^{19}$. Porter's Value Chain Model identifies the activities firm infrastructure, human resource management, technology development and procurement. These so called support activities affect all processes along the entire value chain ${ }^{20}$. Figure 1 shows these approaches in an overview.

\begin{tabular}{|c|c|c|c|}
\hline Approach & Dimensions & Summary & Suitability \\
\hline $\begin{array}{l}\text { 7-5 model } \\
\text { (Mc Kinsey) }\end{array}$ & $\begin{array}{l}\text { - Strategy } \\
\text { - Structure } \\
\text { - Systems } \\
\text { - Style/Culture } \\
\text { - Staff } \\
\text { - Skills } \\
\text { - Shared Values }\end{array}$ & $\begin{array}{l}\text { Change management } \\
\text { approach that divides an } \\
\text { organisation into seven } \\
\text { factors. Each change of one } \\
\text { factor influences any other } \\
\text { factors. }\end{array}$ & $\begin{array}{l}\text { As information procurement and } \\
\text { technology is not regarded, this } \\
\text { approach is not directly } \\
\text { appropriate. }\end{array}$ \\
\hline $\begin{array}{l}5 \text { Factors Model } \\
\text { (Pfeiffer, et al.) }\end{array}$ & $\begin{array}{l}\text { - Input } \\
\text { - Personnel } \\
\text { - Organisation } \\
\text { - Technology } \\
\text { - Output } \\
\end{array}$ & $\begin{array}{l}\text { Closed model for the } \\
\text { structural and procedural } \\
\text { description of industrial } \\
\text { systems. }\end{array}$ & $\begin{array}{l}\text { Cross sectional model that does } \\
\text { not fit in the superior dimension } \\
\text { structure (e.g. Output). }\end{array}$ \\
\hline $\begin{array}{l}\text { Value Chain Model, } \\
\text { Support Activities } \\
\text { (Porter) }\end{array}$ & $\begin{array}{l}\text { - Firm Infrastructure } \\
\text { - Human Resource } \\
\text { Management } \\
\text { - Technology } \\
\text { Development } \\
\text { - Procurement }\end{array}$ & $\begin{array}{l}\text { Divides the support activities } \\
\text { of an enterprise cross } \\
\text { sectional. All Dimensions } \\
\text { affect all processes of the } \\
\text { primary activities along the } \\
\text { entire value chain. Focuses } \\
\text { primarily on manufacturing } \\
\text { industry. Highly established. }\end{array}$ & $\begin{array}{l}\text { Describes all relevant aspects of } \\
\text { the structure dimension. Includes } \\
\text { all relevant sub-dimensions of } \\
\text { the other approaches. }\end{array}$ \\
\hline
\end{tabular}

Figure 1. Overview of Approaches for the Subdivision of the Dimension Structure

The dimensions of the 7-S Model allow a detailed view on the characteristics of an organisation. Some aspects that are relevant for the provision of mobile services (e.g. technology and procurement) are not regarded. Pfeiffer's first four dimensions can be interpreted almost alike the dimensions identified in Porter's Value Chain Model. The additional element output is already subject of the Acceptance dimension. The supporting activities of the Value Chain Model include all relevant aspects of the other approaches. Even if Porter does not explicitly regard the specific characteristics of mobile services, a stronger focus of the procurement on information than on material goods is the only constraint ${ }^{21}$.

Influencing factors for Porter's sub-dimension Firm Infrastructure are financial resources, organizational structure and brands. Human Resource Management contains factors like knowledge as well as the quantity and qualification of personnel. Regarding the sub-dimension Technology Development leads to influencing factors like IT systems, technical standards and experience with emerging technologies. In the sub-dimension 
Procurement influencing factors like content acquisition, information retrieval and situation determinants can be identified. Figure 2 gives an overview on the four sub-dimensions of Structure.

\begin{tabular}{|c|c|}
\hline Sub-Dimensions & Influencing Factors \\
\hline Firm Infrastructure & $\begin{array}{l}\text { - Organizational Structure (e.g existing Structure) } \\
\text { - Financial Resources (e.g. sufficient Ressources) } \\
\text { - Brands (e.g. usable or transferable Brands) }\end{array}$ \\
\hline Human Resource Management & $\begin{array}{l}\text { - Knowledge (e. g. existing knowledge) } \\
\text { - Personnel Quantity (e.g. manpower requirements) } \\
\text { - Personnel Qualification (e.g. key qualifications) }\end{array}$ \\
\hline Technology Developmert & $\begin{array}{l}\text { - IT Systems (e.8. Servers, Content Management Systems) } \\
\text { - Technical Standards (e.g. UDDI, WAP, UMTS) } \\
\text { - Experience with the Integration of Emerging Technologies }\end{array}$ \\
\hline Procurement & $\begin{array}{l}\text { - Content Acquisition (e.g. Contacts, Relationships) } \\
\text { - Information Retrieval (e. g. Information, News, Location Information) } \\
\text { - Technical Procurement (e.g. Server, OS, DB, Software) }\end{array}$ \\
\hline
\end{tabular}

Figure 2. Influencing Factors and Examples in an Overview

\section{PROCESS DIMENSION}

A mobile service can be interpreted as an assessable process of internal and external interactions ${ }^{11}$. The internal interactions include the development of the mobile service. The external interactions refer to the participation of the end-user in planning, developing and providing mobile services.

According to Porter the overall value creating logic of the value chain with its generic categories of primary activities is valid in all industries. Although Porter's framework plays a central role it is challenged in resource-based critiques $^{22,23}$. Considering the weaknesses of Porter's framework two alternative models for the value configuration, the Value Shop and the Value Network, can be discussed ${ }^{24}$.

According to the Value Shop Model the value creation bases on the five dimensions problem finding/acquisition, problem solving, choice, execution and control/evaluation. Within these dimensions a firm relying on intensive technology is able to solve customer or client problems ${ }^{24}$. The Value Network Model considers the main dimensions promotion and contract management, service provisioning and infrastructure operation. This approach focuses on value creation in firms that rely on mediating technology to link clients or customers ${ }^{24}$. The primary activities of Porter's Value Chain Model describe the whole building process of products or services. Porter specifies the dimensions inbound logistics, operations, marketing/sales, outbound logistics and after-sale service as generic activities of the process. This approach originally focuses on manufacturing 
industries $^{20}$. Figure 3 gives an overview of approaches for the subdivision of the Process dimension.

\begin{tabular}{|c|c|c|c|}
\hline Approach & Dimensions & Surnmary & Suitability \\
\hline $\begin{array}{l}\text { Value Shop } \\
\text { (Stabell, Fjeldstad) }\end{array}$ & $\begin{array}{l}\text { - Problem-Finding } \\
\text { and Acquisition } \\
\text { - Problem Solving } \\
\text { - Choice } \\
\text { - Execution } \\
\text { - Control/ Evaluation }\end{array}$ & $\begin{array}{l}\text { Approach for value creation } \\
\text { logic in firms that rely on } \\
\text { intensive technology to solve } \\
\text { a customer or client problem. }\end{array}$ & $\begin{array}{l}\text { Regards the stages of service } \\
\text { provision; relevant aspects of the } \\
\text { Process as information handling } \\
\text { are not considered }\end{array}$ \\
\hline $\begin{array}{l}\text { Value Network } \\
\text { (Stabell, Fjeldstad) }\end{array}$ & $\begin{array}{l}\text { - Promotion and } \\
\text { Contract } \\
\text { Management } \\
\text { - Service } \\
\text { Provisioning } \\
\text { - Infrastructure } \\
\text { Operation } \\
\end{array}$ & $\begin{array}{l}\text { Approach for value creation } \\
\text { logic in firms that rely on } \\
\text { mediating technology to link } \\
\text { clients or customers }\end{array}$ & $\begin{array}{l}\text { Focuses on the value creation of } \\
\text { MNO's; does not consider } \\
\text { relevant aspects as customer care }\end{array}$ \\
\hline $\begin{array}{l}\text { Value Chain Model, } \\
\text { primary activities } \\
\text { (Porter) }\end{array}$ & $\begin{array}{l}\text { - Inbound Logistics } \\
\text { - Operations } \\
\text { - Outbound Logistics } \\
\text { - Marketing and } \\
\text { Sales } \\
\text { - After-Sale Service }\end{array}$ & $\begin{array}{l}\text { Primary activities are directly } \\
\text { inwolved in creating and } \\
\text { bringing value to the } \\
\text { customer. Approach focuses } \\
\text { primarily on manufacturing } \\
\text { industry }\end{array}$ & $\begin{array}{l}\text { Regards all relevant influencing } \\
\text { factors for the structure of } \\
\text { organisations }\end{array}$ \\
\hline
\end{tabular}

Figure 3. Overview of Approaches for the Subdivision of the Dimension Process

As the Value Shop Model especially regards problem solutions it is suitable for analysing concrete aspects of mobile services but not for a profound classification of the Process dimension. Depending on the interpretation the value shop model can be regarded as a subset of Porter's primary activities ${ }^{24}$. The Value Network Model focuses on network providers. From the view of providers of mobile services the provision and operation take place at the same time $e^{25}$. For mobile service providers the contract management is not part of the provisioning process. Taking Bullinger and Schreiner's classification into account it has to be regarded in the Structure dimension?

Regarding mobile services the critiques of Porter's Value Chain Model have no effects on its suitability. The primary activities are appropriate to describe the different stages of value creation of mobile services. They are suitable for a detailed classification of the Process dimension. The only adaptation refers to the generally termed dimensions.

Particularly important for the sub-dimension inbound logistics is the handling of information. The outbound logistics can be reduced on service distribution as mobile services use only digital distribution channels. In addition after-sale service can be termed customer care.

Regarding the sub-dimension Information Handling the transaction standards and the handling of content and situation determinants can be 
identified as influencing factors. The sub-dimension Technical Operations includes influencing factors like service generation, reliability and situation dependency concepts. The analysis of the sub-dimension Service Distribution leads to co-operations, distribution concepts and access technologies. The sub-dimension Marketing contains factors like promotion, placement and price of a mobile service. Customer support, customer relations and service enhancement are influencing factors of the subdimension Customer Care. Figure 4 shows the five sub-dimensions and influencing factors of the Process dimension.

\begin{tabular}{|c|l|}
\hline Sub-Dimensions & \multicolumn{1}{c|}{ Influencing Factors } \\
\hline Information Handling & - Content Handling (e.g. Storage, Databases) \\
& - Transaction Standards (e.g. Interfaces, Technologies) \\
& - Handling of Situation Determinants (e.g. Location Information) \\
\hline Technical Operations & - Service Generation (e.g. Databases, Content Management) \\
& - Reliability (e.g. Security, System Stability) \\
& - Situation Dependency Concepts (e.g. Location, Personalisation) \\
\hline Service Distribution & - Co-operations (e.g. Portals, MNO's, SP's) \\
& - Distribution Concepts (e.g. Push, Pull) \\
& - Access Technologies (e.g. GSM, GPRS, UMTS) \\
\hline \multirow{2}{*}{ Marketing } & - Promotion (e.g. Advertisement, Public Relations) \\
& - Placement (e.g. Target Groups and Markets) \\
& - Price (e.g. Elasticity, Structure) \\
\hline \multirow{2}{*}{ Customer Care } & - Customer Support (e.g. Help Systems, FAQ's, Hotlines) \\
& - Customer Relations (e.g. Controlling, CRM) \\
& - Service Enhancement (e.g. Ideas, Adaptation Mechanisms) \\
\hline
\end{tabular}

Figure 4. Influencing Factors and Examples in an Overview

\section{ACCEPTANCE DIMENSION}

The end-user's acceptance is more and more regarded as a critical factor for the analysis and evaluation of mobile services ${ }^{26}$. The acceptance significantly depends on the end-user's perspective of the mobile service.

The Technology Acceptance Model (TAM) is a highly established model to evaluate the end-user's acceptance and considers the end-user's perception ${ }^{27}$. The Compass Acceptance Model is a model that explicitly regards mobile services. It extends $T A M$ for general conditions that are not determined by the specific mobile service and has been approved in several projects $^{28}$. Another concept that is focused on mobile services is Silberer's layer concept. It focuses on the customer satisfaction of mobile commerce applications. Other acceptance models (e.g. Goodhue, Degenhardt, Kollman) do not regard the specific aspects of mobile services.

According to Davis' Technology Acceptance Model the user acceptance is determined by the factors perceived usefulness and perceived ease of use. 
It regards the acceptance of technologies in general $^{27}$. The Compass Acceptance Model is a model for (re-) evaluating the end-user's acceptance for mobile services ${ }^{26}$. As an extension of TAM it subdivides the influencing factors of the end-user's acceptance into perceived usefulness, perceived ease of use, perceived costs and perceived network effects ${ }^{28}$. Silberer's Customer Satisfaction Approach considers the dimensions hardware, transmission costs and mobile commerce application. Regarding these dimensions experiences, expectations and the conformity of expectations can be examined ${ }^{29}$. Figure 5 gives an overview of approaches for the subdivision of the Acceptance dimension.

\begin{tabular}{|l|l|l|l|}
\hline \multicolumn{1}{|c|}{ Approach } & \multicolumn{1}{c|}{ Dimensions } & \multicolumn{1}{c|}{ Summary } & \multicolumn{1}{c|}{ Suitability } \\
\hline $\begin{array}{l}\text { Technology } \\
\text { Acceptance Model } \\
\text { (Davis) }\end{array}$ & $\begin{array}{l}\text { - Perceived Usefulness } \\
\text { - Perceived Ease of Use }\end{array}$ & $\begin{array}{l}\text { Approach for the (re-) } \\
\text { evaluation of the } \\
\text { acceptance of mobile } \\
\text { services from the end- } \\
\text { user's point of view }\end{array}$ & $\begin{array}{l}\text { Highly established; mobile } \\
\text { services are not regarded } \\
\text { explicitly }\end{array}$ \\
\hline $\begin{array}{l}\text { Compass Acceptance } \\
\text { Model } \\
\text { (Amberg et al.) }\end{array}$ & $\begin{array}{l}\text { - Perceived Usefulness } \\
\text { - Perceived Ease of Use } \\
\text { - Perceived Costs } \\
\text { - Perceived Network } \\
\text { Effects }\end{array}$ & $\begin{array}{l}\text { Approach for the (re-) } \\
\text { eqaluation of the } \\
\text { acceptance of mobile } \\
\text { services from the end- } \\
\text { user's point of view that } \\
\text { expands TAM for mobile } \\
\text { services. }\end{array}$ & $\begin{array}{l}\text { Approach especially for mobile } \\
\text { services that regard all relevant } \\
\text { sub-dimensions of this } \\
\text { dimension from the end-user's } \\
\text { perception. }\end{array}$ \\
\hline $\begin{array}{l}\text { Customer } \\
\text { Satisfaction } \\
\text { (Silberer et al.) }\end{array}$ & $\begin{array}{l}\text { Regards experiences, } \\
\text { expectations and the } \\
\text { conformity of expectations } \\
\text { along three layers. }\end{array}$ & $\begin{array}{l}\text { Approach of conformity of } \\
\text { expectations is suitable. } \\
\text { Usability is not considered } \\
\text { explicitly. }\end{array}$ \\
\hline
\end{tabular}

Figure 5. Overview of Approaches for the Subdivision of the Dimension Acceptance

The Technology Acceptance Model regards the acceptance in general and does not consider mobile aspects explicitly. As Silberer's Customer Satisfaction Model is technology driven, usability aspects are not regarded. The Compass Acceptance Model is specialised on the acceptance of mobile services. It contains all relevant aspects of the other approaches ${ }^{26}$ and is approved for a subdivision of the Acceptance dimension ${ }^{28}$.

Regarding the Perceived Usefulness, influencing factors like added value, emotions and the information quality are relevant. The sub-dimension Perceived Ease of Use contains factors like initial operation, usability of the service and terminal equipment. An assignment of influencing factors for the sub-dimension Perceived Costs leads to factors like monetary costs, transparency of costs and health concerns. The sub-dimension Perceived Network Effects identifies general conditions of mobile services ${ }^{28}$. Influencing factors that affect the mobile service indirectly are the network 
coverage, terminal equipment or the image. Figure 6 shows the four subdimensions of the dimension Outcomes in an overview.

\begin{tabular}{|c|l|}
\hline Sub-Dimensions & \multicolumn{1}{c|}{ Influencing Factors } \\
\hline \multirow{3}{*}{ Perceived Usefulness } & - Added Value (e.g. Fun Factor, Information) \\
& $\begin{array}{l}\text { - Emotions (e.g. Feeling of Independence) } \\
\text { - Information Quality (e.g. Timeliness) }\end{array}$ \\
\hline \multirow{3}{*}{ Perceived Ease of Use } & - Initial Operation (e.g. Registration, First Configuration) \\
& - Usability Service (e.g. Intuitive Handling, Idle Time) \\
& - Usability Terminal Equipment (e.g. Display, Keypad) \\
\hline Perceived Costs & - Monetary Costs (e.g. Purchasing Costs, Basic Rates, Usage Costs) \\
& - Transparency (e.g. Tariff Models, Cost per Minute/Request/Bit) \\
& - Health Concerns (e.g. Dangerous Radiation) \\
\hline \multirow{2}{*}{ Perceived Network Effects } & - Network Coverage (e.g. Dissemination, Roaming) \\
& - Terminal Equipment (e.g. Design. Size, Colour) \\
& - Image (e.g. Service as Status Symbol, Group A.ffiliation) \\
\hline
\end{tabular}

Figure 6. Influencing Factors and Examples in an Overview

\section{MARKET DIMENSION}

During the early stage of the development of mobile services the consideration of the market plays an important role ${ }^{4}$. Current best practices for planning are often based on speculations about the market of mobile services $^{30}$. This inadequate market orientation is a main reason for deficits in the development of services ${ }^{31}$.

Regarding the market and its actors leads to Porter's Five Forces Model of competitive advantage that is highly established. Grove extended Porter's model by the sixth force Complementors. Regarding the telecommunication business Downes criticises this model due to adaptations to actual developments. He suggests a Three Forces Model. An alternative perception to classify this dimension is to regard the participants of mobile markets. Following this approach various models exist. These so called value chain models specify the actors in a varying level of abstraction. The Wireless Value Chain is a representative model that subsumes the relevant aspects as a superset.

For a classification of the Market dimension it has to be considered how promising the market and how competitive a service is. Porter terms this as competitive advantage ${ }^{32}$. He identifies Competitors, Customers, Suppliers, Substitutes and Potential Competitors as the five forces of competitive advantage. Grove enhanced this model with Complementors (e.g. Portals for Mobile Services) as a sixth force ${ }^{33}$. Downes regards these factors as inadequate for the consideration of digital services. Therefore he proposes the factors digitalisation, globalisation and deregulation as new forces for 
the determination of the competitive advantage in times of economical changes $^{34}$. JP Morgan's Wireless Value Chain provides a detailed classification of actors of mobile business. It specifies the categories equipment, networks, software and services ${ }^{35}$. Figure 7 gives an overview of approaches for the subdivision of the Market dimension.

\begin{tabular}{|l|l|l|l|}
\hline \multicolumn{1}{|c|}{ Approach } & \multicolumn{1}{|c|}{ Dimensions } & \multicolumn{1}{c|}{ Summary } & \multicolumn{1}{c|}{ Suitability } \\
\hline $\begin{array}{l}\text { 6 Forces } \\
\text { (Grove) }\end{array}$ & $\begin{array}{l}\text { - Competitors } \\
\text { - Complementors } \\
\text { - Customers } \\
\text { - Suppliers } \\
\text { - Substitutes } \\
\text { - Potential Competitors }\end{array}$ & $\begin{array}{l}\text { Enhances Porter's 5 Forces } \\
\text { Mocel with the power, } \\
\text { vigor and competence of } \\
\text { complementors that are } \\
\text { highly relevant for mobile } \\
\text { services (e.g. terminal } \\
\text { equipment) }\end{array}$ & $\begin{array}{l}\text { Regards all relevant } \\
\text { influencing factors for the } \\
\text { market of mobile services. }\end{array}$ \\
\hline $\begin{array}{l}\text { 3 Forces } \\
\text { (Downes) }\end{array}$ & $\begin{array}{l}\text { - Digitalisation } \\
\text { - Globalisation }\end{array}$ & $\begin{array}{l}\text { Criteria for the considera- } \\
\text { tion of services underlying } \\
\text { economical trends }\end{array}$ & $\begin{array}{l}\text { Criteria only valid in certain } \\
\text { times; focuses on external } \\
\text { influences on the market }\end{array}$ \\
\hline $\begin{array}{l}\text { Wireless Value } \\
\text { Chain } \\
\text { (JP Morgan) }\end{array}$ & $\begin{array}{l}\text { - Equipment } \\
\text { - Setworks } \\
\text { - Solware } \\
\text { - Services }\end{array}$ & $\begin{array}{l}\text { Approach for structuring } \\
\text { the players in Mobile } \\
\text { Business. }\end{array}$ & $\begin{array}{l}\text { Regards all relevant market } \\
\text { players; does not consider } \\
\text { competition (e.g. Substitutes) }\end{array}$ \\
\hline
\end{tabular}

Figure 7. Overview of Approaches for the Subdivision of the Dimension Market

The Wireless Value Chain provides all relevant actors of value creation in mobile business. As it does not consider competition explicitly, it is not directly applicable for a subdivision of the Market dimension. Downes' three forces clarify the difficulties in regarding the market and its players due to external influences. The actors itself are not directly considered. Grove's Six Forces Model provides all relevant aspects of competitive advantages for the market and contains all significant aspects that are regarded by the other models. Therefore the Six Forces Model appears to be an adequate approach for a detailed classification of the Market dimension.

The sub-dimension Competitors includes influencing factors like service providers, mobile network operators and hybrid products that are competing in the same market. Mobile devices, portals and independent payment systems can be assigned to the sub-dimension Complementors. An actual example for the influence of Complementors is the lack of UMTS devices for the European market. The sub-dimension Customers includes factors like requirements, quantities and properties of potential end-users. The subdimension Suppliers is influenced by mobile network operators (in their primary role as MNO, not as service provider), content providers and third parties (e.g. for billing or encashment). The sub-dimension Substitutes contains traditional "non mobile" products as well as emerging technologies and new approaches for the replacement of mobile services. Besides actual 
competitors new or already existing SP's or traditional enterprises may enter the market and have to be regarded as Potential Competitors. Figure 8 shows the six sub-dimensions of Market.

\begin{tabular}{|c|c|}
\hline Sub-Dimensions & Influencing Factors \\
\hline Competitors & $\begin{array}{l}\text { - Other SP's that provide equal services } \\
\text { - MNO's (in their role as SP) that provide equal services } \\
\text { - Hybrid products (e.g. Service Combinations, Broadcast Information) }\end{array}$ \\
\hline Complementors & $\begin{array}{l}\text { - Portals and Platforms (Startpage of MNO or Interme diate) } \\
\text { - Mobile Devices (e.g. Required Technologies) } \\
\text { - Independent Payment Systems (e.g. PayPal, MoxMo) }\end{array}$ \\
\hline Customers & $\begin{array}{l}\text { - Requirements (e.g. Demands, Needs) } \\
\text { - Quantity (e.g. Potential End-Users, Market Size) } \\
\text { - Properties (e.g. Structure and Altributes) }\end{array}$ \\
\hline Suppliers & $\begin{array}{l}\text { - MNO's (Guidelines, Techoology, Location Information) } \\
\text { - Content Provider (e.g. Monopoles, Timeliness, Pricing) } \\
\text { - Third Parties (e.g. Billing Encashment) }\end{array}$ \\
\hline Substitutes & $\begin{array}{l}\text { - "Non Mobile" Products (e.g. Map instead of Navigation Service) } \\
\text { - Ernerging Technologies (e.g. Faster, Smaller, Better) } \\
\text { - New Approaches (e.g. Automation instead of Mobile Service) }\end{array}$ \\
\hline Potential Competitors & $\begin{array}{l}\text { - Emerging SP's (e.g. Entrepreneurs) } \\
\text { - Existing SP's (e.g. expanding existing services) } \\
\text { - Traditional Enterprises (e.g. expanding with mobile strategies) }\end{array}$ \\
\hline
\end{tabular}

Figure 8. Influencing Factors and Examples in an Overview

\section{FRAMEWORK}

Initial point of this paper was the need for a systematic classification for identifying factors influencing the design of mobile services. As suitable approaches that directly address mobile services currently do not exist, different scientific approaches from nearby research disciplines were evaluated. By combining selected approaches a theory based framework for the classification of influencing factors was derived in a two step process. It identifies the four basic dimensions Structure, Processes, Acceptance and Market. For the subdivision of these dimensions, different approaches were selected and discussed. Based on this discussion sub-dimensions for the classification were derived. To evaluate the appropriateness of this classification representative influencing factors were identified for each subdimension.

For the dimensions Structure and Process Porter's Value Chain Model was applied. For the dimension Acceptance the Compass Acceptance Model was selected. For the subdivision of the Market Grove's Six Forces Model was used. Figure 9 shows the four dimensions and all sub-dimensions in an overview. 


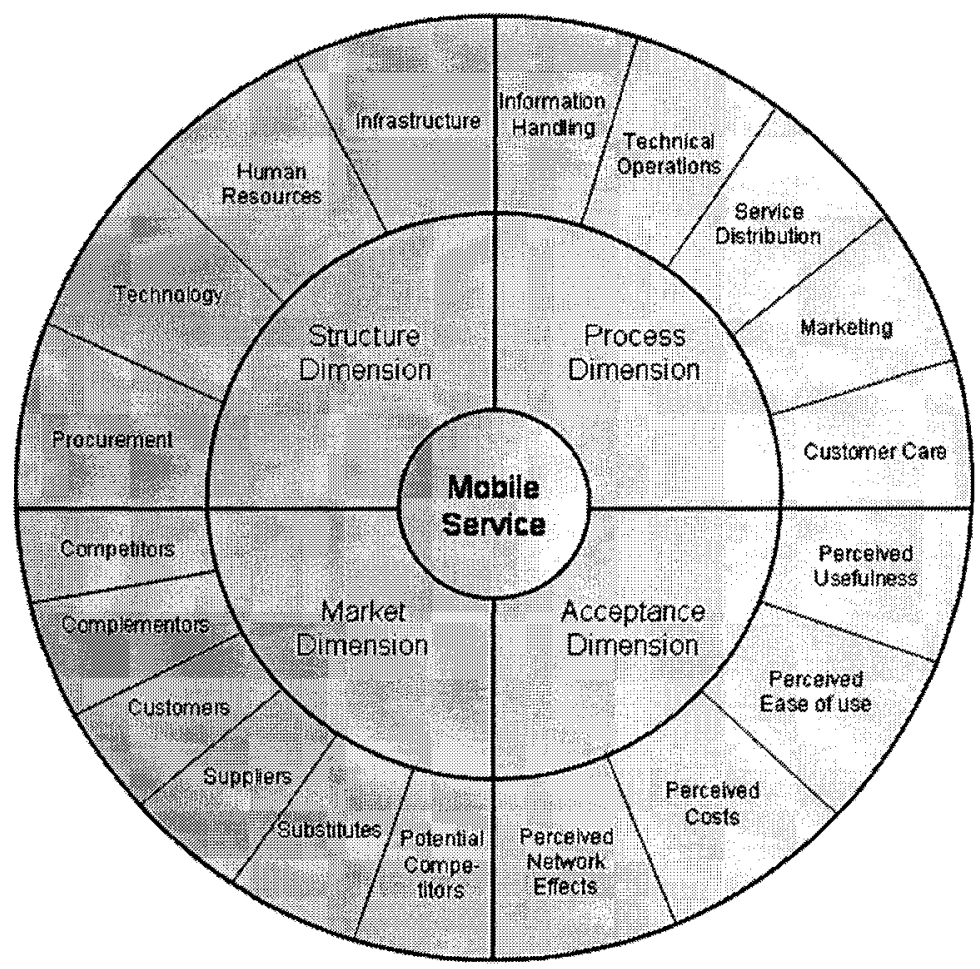

Figure 9. Classification of Influencing Factors

From the theoretical point of view, the derived dimensions appear suitable for identifying a balanced set of influencing factors. First experiences in the context of practical projects confirmed the suitability of the framework for the complete and disjunctive classification of influencing factors of mobile services.

\section{OUTLOOK}

The presented framework for the classification of influencing factors of mobile services is expected to lead to a significant improvement of the transparency of relevant influencing factors for the design of mobile services. Additionally, the framework can be applied for comparing and benchmarking different mobile services. Furthermore it can be used for planning (e.g. for the selection of mobile services in the early stages) or the controlling of mobile services during the product lifecycle. To prove its significance, the framework has to be challenged by an empirical validation. 
Need for further research is seen in the qualitative and quantitative measurement of influencing factors. Especially the identification of suitable criteria, combinations between qualitative and quantitative criteria, weighting factors and the visualisation of results have to be regarded in the future. Furthermore the availability and suitability of methods for these aspects have to be analysed.

As a future target, the framework can be expanded for a support of appropriate measures considering effort and benefit for the evaluations of mobile services. Due to the general validity of the identified and selected approaches it is expected that the framework can be applied for services in general as well.

\section{REFERENCES}

1. Gartner Group: GPRS will not succeed until new Technologies are developed, Press Release, June 3, 2002.

2. Geer, R.; Gross, R.: M-Commerce. Geschäftsmodelle für das mobile Internet, Landsberg/Lech, 2001.

3. Böcker, F.; Kotzbauer, N.: Einflussgrößen des Erfolgs von Markteinführungen industrieller Produkte, Arbeitspapier 52 des Instituts für Betriebswirtschaftlehre der Universität Regensburg, Regensburg, 1989.

4. Lehner, F.: Mobile und drahtlose Informationssysteme. Technologien, Anwendungen, Märkte, Heidelberg, 2003.

5. Benkenstein, M.: Dienstleistungsqualität: Anpassungen zur Messung und Implikationen für die Steuerung. In: Zeitschrift für Betriebswirtschaft, 1993, 63. Jg., Heft 11, p. 10951116.

6. Amberg, M.; Wehrmann, J.; Zimmer, R.: Towards a Theory Based Identification of Influencing Factors for the Design of Mobile Services. In Aguilar, J. et al. (Eds.): Proceedings 10th International Conference on Cybernetics and Information Technologies, Systems and Application (CITSA), Florida, 2004.

7. Bullinger, H.-J.; Schreiner, P.: Service Engineering: Ein Rahmenkonzept für die systematische Entwicklung von Dienstleistungen. In: Bullinger, H.-J.; Scheer, A.-W.: Service Engineering - Entwicklung und Gestaltung innovativer Dienstleistungen, 2003, p. 51-82.

8. Donabedian, A.: Evaluating the quality of medical care. In: Milbank Memorial fund Quarterly, 1966, 44. Jg., Heft 3, Part 2, p. 166-203.

9. Ramaswamy, R.: Design and Management of Service Processes, Boston, 1996.

10.Deutsches Institut für Normung DIN: Qualitätsmanagement und Elemente eines Qualitätssicherungssystems. Leitfaden für Dienstleistungen DIN EN ISO 9004-2, Berlin, 1992.

11.Edvardsson, B.; Olsson, J.: Key concepts for new service development. In: The Service Industries Journal, 1996, 16. Jg., Heft 2, p. 140-164.

12.Corsten, H.: Dienstleistungsmanagement, München, 2001.

13. Grieble, O.; Scheer, A.-W.: Grundlagen des Benchmarkings öffentlicher Dienstleistungen. In: Scheer, A.-W. (Hrsg.): Veröffentlichungen des Instituts für Wirtschaftsinformatik, Nr. 166, Saarbrücken, 2000. 
14.Donabedian, A.: The definition of quality and approaches to its assessment, explorations, quality, assessment and monitoring, Michigan, 1980.

15.Meyer, C.; Mattmüller, R.: Qualität von Dienstleistungen - Entwurf eines praxisorientierten Qualitätsmodells. In: Marketing - Zeitschrift für Forschung und Praxis ZFP, 1987, 9. Jg., Heft 3, p. 187-195.

16. Galletta, D. F.; Malhotra, Y.: Extending the technology acceptance model to account for social influence: theoretical bases and empirical validation. In: Proceedings of the 32nd Hawaii International Conference on System Sciences, 1999, p. 6-19.

17.Engelhardt, W. H.; Kleinaltenkamp, M.; Reckenfelderbäumer, M.: Dienstleistungen als Absatzobjekt. In: Veröffentlichungen des Instituts für Unternehmensführung und Unternehmensforschung, Arbeitsbericht Nr. 52, Bochum, 1992.

18.Peters, T.; Waterman, R.: In Search of Excellence, New York, 1982.

19.Pfeiffer, W.; Weiß, E.; Strubl, C.: Systemwirtschaftlichkeit: Konzeption und Methodik zur betriebswirtschaftlichen Fundierung innovationsorientierter Entscheidungen, 1994.

20.Porter, M. E.: Competitive Strategy: Techniques for Analysing Industries and Competitors, New York, 1980.

21.Amberg, M.; Wehrmann, J.: Effizientes Angebot von situationsabhängigen mobilen Diensten. In: Zeitschrift Industrie Management, 2003, Ausgabe 06/2003, p. 35-37.

22. Barney, J. B.: Firm resources and sustained advantage. In: Journal of Management, 1991, Vol. 17, p. 19-120.

23. Wernerfelt. B.: A resource-based view of the firm. In: Strategic Management Journal, 1984, Vol. 5(2), p. 171-180.

24.Stabell, C. B.; Fjeldstad, O. D.: Configuring Value for Competitive Advantage: on Chains, Shops and Networks. In: Strategic Management Journal, 1998, Vol. 19, p. 413 - 437.

25.Meiren, T.: Entwicklung von Dienstleistungen unter besonderer Berücksichtigung von Human Ressources. In: Bullinger, H.J.: Entwicklung und Gestaltung innovativer Dienstleistung. Tagungsband zur Service Engineering 2001, (IAO) Stuttgart, 2001.

26.Amberg, M.; Hirschmeier, M.; Wehrmann, J.: The Compass Acceptance Model for the Analysis and Evaluation of Mobile Information Systems. In: International Journal for Mobile Communications (IJMC), 2004, Vol. 2, N 3.

27.Davis, F. D.: Perceived Usefulness, Perceived Ease of Use, and User Acceptance of Information Technology. In: MIS Quarterly, 1989, Vol. 13, No. 3 (8/1989), p.319-341.

28. Amberg, M.; Wehrmann, J.: Benutzerakzeptanz mobiler Dienste. Ein Erfahrungsbericht zum Compass-Akzeptanzmodell, Arbeitsbericht Nr. 02/2003 des Lehrstuhls für Wirtschaftsinformatik III, Friedrich-Alexander Universität Erlangen-Nürnberg, Nürnberg, 2003.

29.Silberer, G.; Magerhans, A.; Wohlfahrt, J.: Kundenzufriedenheit und Kundenbindung im Mobile Commerce. In: Silberer, G.; Wohlfahrt, J.; Wilhelm, T. (Eds.): Mobile Commerce. Grundlagen, Geschäftsmodelle, Erfolgsfaktoren. Wiesbaden, 2002, p. $309-324$.

30.Strebel, H.: Klein- und Mittelunternehmen in Technologie- und Innovationsnetzwerken. In: Schwarz, E.J. (Eds.): Technologieorientiertes Innovationsmanagement, 2003, p. 62-74.

31.Jenner, T.: Überlegungen zur Integration des Kunden in das Innovationsmanagement. In: Jahrbuch der Absatz- und Verbraucherforschung, 2000, 46. Jg., Heft 2, p. 130-147.

32.Porter, M. E.: Competitive Advantage. New York, 1985.

33. Grove, A. S.: Only the Paranoid Survive, London, 1988.

34.Downes, L.; Mui, C.: Unleashing the Killer App. Boston, 1998.

35.Parlett, T.: A Public Market Perspective: Recipes for Success, JP Morgan, 2000. 